\title{
Studi Eksperimental Dan Analisa Pengaruh Sinar Matahari Terhadap Laju Keausan Material Ethylene Propylene Diene Monomers (EPDM) Pada Wiper Blade
}

\author{
Muzayin Ahmad Fu'adi dan Yusuf Kaelani \\ Departemen Teknik Mesin, Fakultas Teknologi Industri, Institut Teknologi Sepuluh Nopember (ITS) \\ e-mail:y_kaelani@me.its.ac.id
}

\begin{abstract}
Abstrak-Wiper merupakan komponen yang sangat penting dan erat hubungannya dengan keselamatan pengendara terutama pada saat turun hujan karena wiper blade akan menyapu air hujan yang jatuh ke kaca mobil. Pada saat wiper blade bekerja akan terjadi gesekan pada material wiper blade dengan kaca yang dapat mengakibatkan adanya keausan pada material wiper yang biasanya terbuat dari rubber dengan jenis Ethylene Propylene Diene Monomers (EPDM). Penelitian untuk mengetahui pengaruh sinar matahari terhadap laju keausan (wear rate) dan life time dari material wiper blade dilakukan menggunakan tribometer pin on disk dengan variasi material pada pin berupa material Ethylene Propylene Diene Monomers (EPDM) dan Nitrile Rubber (NBR) dimana pada masing-masing material disinari matahari dengan lama waktu yang berbeda yaitu tanpa penyinaran, dengan 100 jam penyinaran, dan dengan 200 jam penyinaran. Kecepatan putar yang digunakan adalah 31,3 rpm dengan pembebanan 14,71 $\mathrm{N}$ dan panjang lintasan $1000 \mathrm{~m}$. Berdasarkan penelitian yang telah dilakukan, dapat diketahui bahwa nilai specific wear rate dari material Ethylene Propylene Diene Monomers (EPDM) dan material Nitrile Rubber (NBR) akan semakin besar seiring semakin lama material terkena matahari. Life time terbaik untuk material Ethylene Propylene Diene Monomers (EPDM) adalah sekitar 3,7 tahun dan life time terbaik untuk material Nitrile Rubber (NBR) adalah sekitar 5,5 tahun. Material Nitrile Rubber (NBR) memiliki ketahanan terhadap keausan serta life time lebih baik daripada material Ethylene Propylene Diene Monomers (EPDM) sehingga dapat dijadikan sebagai material pengganti.
\end{abstract}

Kata Kunci-Wiper, Wiper Blade, Epdm, Nbr, Wear Rate, Life Time.

\section{PENDAHULUAN}

$\mathrm{T}$ RIBOLOGI adalah ilmu yang mempelajari peristiwa interaksi dua permukaan yang bergerak relatif satu terhadap lainnya, dimana didalamnya terdapat fenomena gesekan, pelumasan, dan keausan yang memberikan kontribusi dalam upaya meminimalkan keausan akibat kontak antara dua permukaan, sehingga dapat diterapkan di industri untuk menganalisa kasus kegagalan atau kerusakan. Keausan terjadi apabila terdapat dua atau lebih benda yang saling menekan dan bergesekan.

Salah satu fenomena gesekan yang terjadi dalam dunia otomotif adalah gesekan yang terjadi antara wiper blade dan kaca mobil. Wiper blade merupakan komponen yang sangat penting dan erat hubungannya dengan keselamatan pengendara terutama pada saat turun hujan karena wiper blade dapat menjamin pandangan pengendara agar tidak terhalang oleh air hujan dengan cara menyapu air hujan yang jatuh ke kaca mobil. Pada saat wiper blade bekerja, akan terjadi gesekan pada material wiper blade dengan kaca yang dapat mengakibatkan adanya keausan pada material wiper. Material yang biasanya digunakan pada wiper blade mobil adalah bahan rubber dengan jenis Ethylene Propylene Diene Monomers (EPDM) dimana pada material ini biasa terjadi keausan karena bergesekan dengan kaca mobil [1]. Karena adanya fenomena keausan tersebut, lama kelamaan material rubber akan dapat menimbulkan goresan-goresan pada kaca mobil yang dapat mengganggu pandangan pengendara. Selain itu, adanya keausan pada wiper blade akan mengurangi fungsi dari wiper menjadi kurang sempurna dikarenakan air yang jatuh ke kaca mobil tidak tersapu secara sempurna. Akibatnya air yang tertinggal akan mengganggu pandangan pengendara.

Pada saat mobil berada di ruang terbuka pada siang hari, mobil akan terkena sinar matahari untuk waktu yang lama dimana akan berpengaruh pada keausan material rubber pada wiper blade. Laju keausan semakin buruk ketika material Ethylene Propylene Diene Monomers (EPDM) terkena sinar matahari untuk waktu yang lama. Semakin lama intensitas material terkena sinar matahari maka laju keausan juga akan semakin naik. Pengaruh dari ozon dan pancaran sinar ultraviolet dari sinar matahari dapat merusak struktur kimia pada material rubber sehingga lama-kelamaan material rubber mengalami pengerasan dan mengurangi elastisitas dari rubber. Material rubber yang semakin keras dan tidak elastis akan berdampak pada laju keausan dari material tersebut dimana laju keausan material tersebut akan semakin naik. Oleh karena itu, pada tugas akhir ini akan dilakukan penelitian terhadap laju keausan material Ethylene Propylene Diene Monomers (EPDM) untuk mengetahui wear rate coefficient dan life time material sehingga dapat dilakukan pencegahan terhadap kerusakan pada wiper blade untuk mencegah timbulnya goresan-goresan pada kaca mobil akibat gesekan antara kaca dengan wiper blade karena material Ethylene Propylene Diene Monomers (EPDM) terauskan., serta mencari material 
alternatif yang dapat digunakan sebagai pengganti dari material Ethylene Propylene Diene Monomers (EPDM) dengan wear rate coefficient dan life time yang lebih baik.

\section{METODE PENELITIAN}

Metode Penelitian dilakukan secara eksperimental atau analitis, yaitu pengambilan data secara langsung dan dilakukan perhitungan untuk mendapatkan nilai specific wear rate dan struktur permukaan dari permukaan spesimen uji.

\section{A. Penentuan Parameter}

Tahap ini merupakan langkah awal dalam melakukan pengambilan data. Pengujian dilakukan dengan menggunakan tribometer tipe pin-on-disk. Parameter yang dapat ditentukan untuk pengujian meliputi kecepatan putar disk yaitu 31,3 rpm, panjang lintasan sepanjang $1000 \mathrm{~m}$, serta pembebanan sebesar $14,71 \mathrm{~N}$.

\section{B. Persiapan Spesimen}

Spesimen yang digunakan pada penelitian ini berupa Ethylene Propylene Diene Monomers (EPDM) dan Nitrile Rubber (NBR) sebagai pin dan kaca sebagai disk. Untuk material Ethylene Propylene Diene Monomers (EPDM) dan Nitrile Rubber (NBR) divariasikan menjadi 3 yaitu tanpa penyinaran matahari, dengan penyinaran matahari selama 100 jam, dan dengan penyinaran matahari selama 200 jam. Pin dan disk didesain seperti Gambar 1 dan Gambar 2.

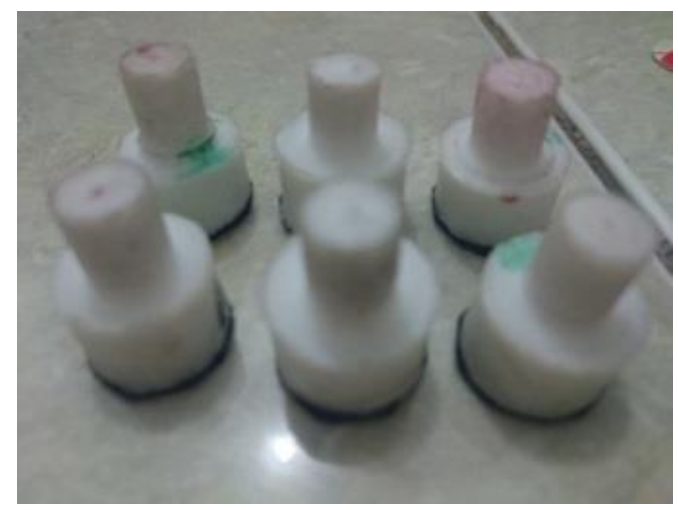

Gambar 1. Pin.

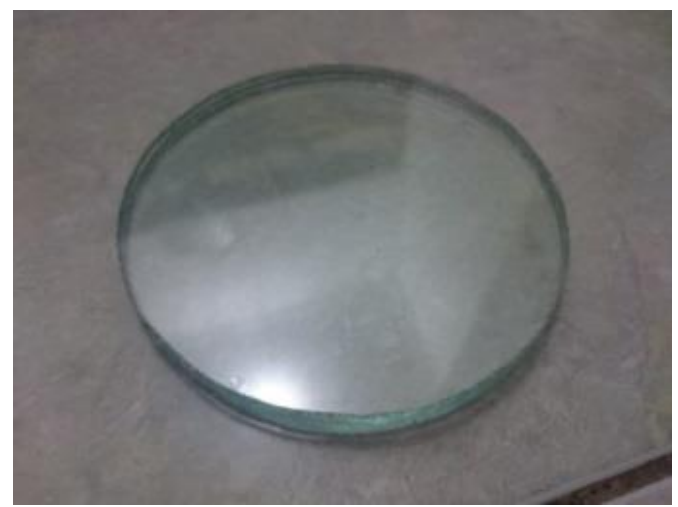

Gambar 2. Disk.

\section{Pengambilan Data Penelitian}

Tahap ini merupakan tahapan yang penting karena pada tahap inilah akan dilakukan penelitian yang nantinya akan digunakan sebagai bahan pembahasan serta analisa. Dari pengujian yang dilakukan didapatkan data berupa massa akhir dan massa awal spesimen.

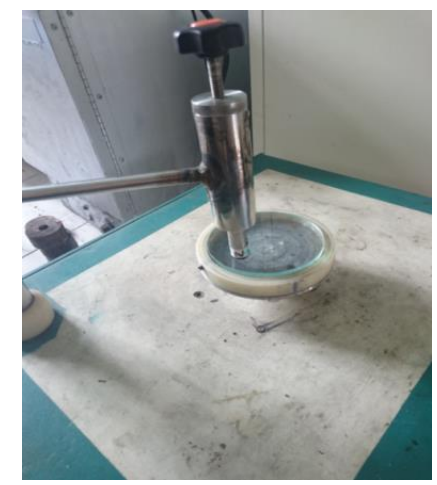

Gambar 3. Pengujian Dengan Tribometer

\section{Perhitungan Volume Aus}

Perhitungan volume aus dapat dilakukan setelah pengujian dengan cara menimbang massa awal spesimen sebelum diuji dan massa akhir spesimen setelah diuji. Selisih dari massa awal dan massa akhir spesimen merupakan massa spesimen yang terkikis. Volume aus dapat dihitung dengan menggunakan persamaan:

$$
V=\frac{m}{\rho}
$$

$$
\begin{aligned}
& \text { Keterangan : } \\
& \mathrm{V} \quad=\text { volume material yang terkikis }(\mathrm{mm}) \\
& \mathrm{m} \quad=\text { massa material yang terkikis }(\mathrm{gram}) \\
& \rho \quad=\text { massa jenis material }\left(\mathrm{gram} / \mathrm{mm}^{3}\right)[2],[3]
\end{aligned}
$$

\section{E. Perhitungan Wear Rate dan Analisa}

Spesimen yang telah dilakukan pengujian selanjutnya akan dihitung besar specific wear rate dan umur hidup (life time) dengan beberapa persamaan yang kemudian akan dilakukan analisa tentang wear rate tersebut. Nilai dari specific wear rate dapat dihitung menggunakan persamaan:

$$
K=\frac{\Delta V}{F \cdot L}
$$

Keterangan :

$\mathrm{K}=$ specific wear rate $\left(\mathrm{mm}^{3} / \mathrm{Nm}\right)$

$\Delta \mathrm{V}=$ volume material yang terkikis $\left(\mathrm{mm}^{3}\right)$

$\mathrm{F}=$ pembebanan (Newton)

$\mathrm{L}=$ panjang lintasan (meter) [2], [3]

Setelah dilakukan perhitungan nilai specific wear rate, selanjutnya dilakukan perhitungan umur hidup (wear rate) material dengan menggunakan persamaan:

$$
t=\frac{L}{v}
$$

Keterangan :

$\mathrm{t}=$ umur hidup material (second)

$\mathrm{L} \quad=$ panjang lintasan (meter)

$\mathrm{v} \quad=$ kecepatan rata-rata $(\mathrm{m} / \mathrm{s})[3]$

Dimana nilai L didapatka dari persamaan:

$$
L=\frac{\Delta V}{K \cdot F}
$$

Keterangan :

$\mathrm{L} \quad=$ panjang lintasan (meter)

$\Delta \mathrm{V}=$ volume batas aus yang diijinkan $\left(\mathrm{mm}^{3}\right)$

$\mathrm{K}=$ specific wear rate $\left(\mathrm{mm}^{3} / \mathrm{Nm}\right)$

$\mathrm{F} \quad=$ pembebanan $(\mathrm{N})[3]$ 


\section{F. Foto Mikro dengan Perbesaran 100X}

Setelah spesimen diuji selanjutnya akan dilakukan foto mikro menggunakan mikroskop dengan perbesaran 100 kali untuk mengetahui kondisi permukaan spesimen uji setelah dilakukan pengujian. Dengan adanya foto mikro tersebut, dapat diketahui jenis keausan yang terjadi apakah keausan abrasif, keausan adhesif, atau keausan fatigue [2].

\section{G. Analisa Hasil dan Kesimpulan}

Dari pengujian yang telah dilakukan akan diperoleh beberapa data yang nantinya akan dianalisa specific wear rate dan kondisi permukaan, kemudian dibandingkan antar spesimen untuk selanjutnya didapatkan suatu kesimpulan dari keseluruhan penelitian.

\section{ANALISA HASIL DAN PEMBAHASAN}

\section{A. Ethylene Propylene Diene Monomers (EPDM)}

Hasil dari pengujian laju keausan pada material Ethylene Propylene Diene Monomers (EPDM) dapat dilihat pada tabel dibawah ini:

Tabel 1

Data perhitungan specific wear rate pada material Ethylene Prophylene Diene Monomers (EPDM) tanpa penyinaran matahari

\begin{tabular}{ccccccc}
\hline \hline $\begin{array}{c}\text { Spes } \\
\text { imen }\end{array}$ & $\begin{array}{c}\Delta \mathrm{m} \\
(\mathrm{gr})\end{array}$ & $\begin{array}{c}\rho \\
\left(\mathrm{gr} / \mathrm{cm}^{3}\right)\end{array}$ & $\begin{array}{c}\Delta \mathrm{V} \\
\left(\mathrm{mm}^{3}\right)\end{array}$ & $\begin{array}{c}\mathrm{s} \\
(\mathrm{m})\end{array}$ & $\mathrm{F}(\mathrm{N})$ & $\begin{array}{c}\mathrm{K} \\
\left(\mathrm{mm}^{3} / \mathrm{Nm}\right)\end{array}$ \\
\hline 1 & 0,0046 & 0,86 & $\begin{array}{c}2,790697 \\
67\end{array}$ & 1000 & 14,715 & $\begin{array}{c}0,0001896 \\
5\end{array}$ \\
2 & 0,0050 & 0,86 & $\begin{array}{c}3,255813 \\
95\end{array}$ & 1000 & 14,715 & $\begin{array}{c}0,0002212 \\
58\end{array}$ \\
3 & 0,0057 & 0,86 & $\begin{array}{c}2,906976 \\
74\end{array}$ & 1000 & 14,715 & $\begin{array}{c}0,0001975 \\
52\end{array}$ \\
\hline \hline
\end{tabular}

Tabel 2

Data perhitungan specific wear rate pada material Ethylene Prophylene Diene Monomers (EPDM) dengan penyinaran $100 \mathrm{jam}$

\begin{tabular}{ccccccc}
\hline \hline $\begin{array}{c}\text { Spes } \\
\text { imen }\end{array}$ & $\begin{array}{c}\Delta \mathrm{m} \\
(\mathrm{gr})\end{array}$ & $\begin{array}{c}\rho \\
\left(\mathrm{gr} / \mathrm{cm}^{3}\right)\end{array}$ & $\begin{array}{c}\Delta \mathrm{V} \\
\left(\mathrm{mm}^{3}\right)\end{array}$ & $\mathrm{s}(\mathrm{m})$ & $\mathrm{F}(\mathrm{N})$ & $\begin{array}{c}\mathrm{K} \\
\left(\mathrm{mm}^{3} / \mathrm{Nm}\right)\end{array}$ \\
\hline 1 & 0,0043 & 0,86 & $\begin{array}{c}3,139534 \\
88\end{array}$ & 1000 & 14,715 & $\begin{array}{c}0,00021335 \\
6\end{array}$ \\
2 & 0,0055 & 0,86 & $\begin{array}{c}3,372093 \\
02\end{array}$ & 1000 & 14,715 & 0,00022916 \\
3 & 0,0052 & 0,86 & $\begin{array}{c}3,372093 \\
02\end{array}$ & 1000 & 14,715 & 0,00022916 \\
\hline \hline
\end{tabular}

Tabel 3

Data perhitungan specific wear rate pada material Ethylene Prophylene Diene Monomers (EPDM) dengan penyinaran 200 jam

\begin{tabular}{ccccccc}
\hline \hline $\begin{array}{c}\text { Spes } \\
\text { imen }\end{array}$ & $\begin{array}{c}\Delta \mathrm{m} \\
(\mathrm{gr})\end{array}$ & $\begin{array}{c}\rho \\
\left(\mathrm{gr} / \mathrm{cm}^{3}\right)\end{array}$ & $\begin{array}{c}\Delta \mathrm{V} \\
\left(\mathrm{mm}^{3}\right)\end{array}$ & $\mathrm{s}(\mathrm{m})$ & $\mathrm{F}(\mathrm{N})$ & $\begin{array}{c}\mathrm{K} \\
\left(\mathrm{mm}^{3} / \mathrm{Nm}\right)\end{array}$ \\
\hline 1 & 0,0051 & 0,86 & $\begin{array}{c}3,720930 \\
23\end{array}$ & 1000 & 14,715 & $\begin{array}{c}0,0002528 \\
66\end{array}$ \\
2 & 0,0055 & 0,86 & $\begin{array}{c}3,604651 \\
16\end{array}$ & 1000 & 14,715 & $\begin{array}{c}0,0002449 \\
64\end{array}$ \\
3 & 0,0056 & 0,86 & $\begin{array}{c}3,953488 \\
37\end{array}$ & 1000 & 14,715 & $\begin{array}{c}0,0002686 \\
71\end{array}$ \\
\hline \hline
\end{tabular}

B. Analisa Laju Keausan Pada Material Ethylene Propylene Diene Monomers (EPDM)

Dari data yang ada, dapat dianalisa berapa nilai specific wear rate yang menunjukkan besarnya volume aus atau bagian yang terkikis setiap satu satuan gaya dan jarak. Besarnya specific wear rate yang didapatkan dari hasil pengujian keausan untuk material Ethylene Propylene Diene
Monomers (EPDM) dengan variasi 100 jam penyinaran, 200 jam penyinaran, dan tanpa adanya penyinarandapat dilihat pada Gambar 4.



Gambar 4. Grafik Specific Wear Rate terhadap Lama Penyinaran Matahari pada material Ethylene Propylene Diene Monomers (EPDM).

Dari Gambar 4 dapat dilihat bahwa pada material ethylene propylene diene monomers (EPDM) dilakukan 3 kali percobaan untuk setiap variasi penyinaran dengan menghasilkan nilai specific wear rate yang tidak terlalu berbeda jauh. Akan tetapi pada percobaan kedua pada material yang tidak disinari matahari, perbedaan yang timbul cukup berbeda jauh. Perbedaan yang ada disebabkan karena saat pengujian, pembebanan tidak memberikan penekanan yang sempurna. Penekanan dari beban seharusnya terjadi secara konstan, namun kenyataannya penekanan beban mengalami osilasi.

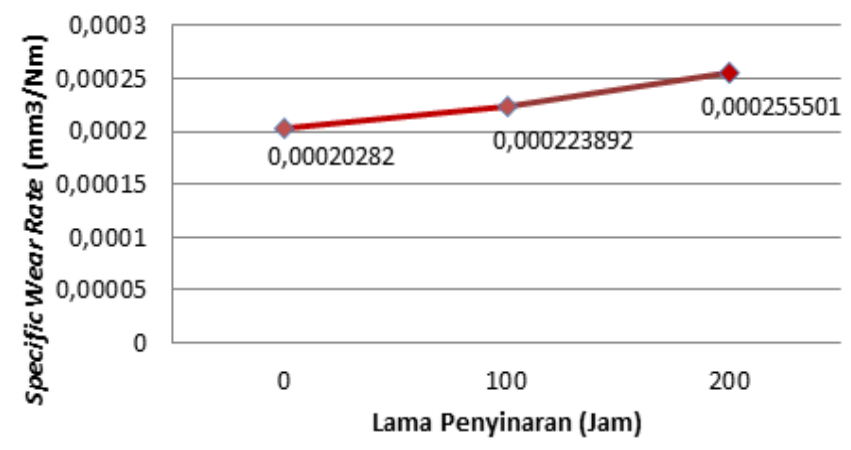

Gambar 5. Grafik Specific Wear Rate Rata-rata terhadap Lama Penyinaran Matahari pada Material Ethylene Propylene Diene Monomers (EPDM).

Pada Gambar 5, terlihat tren grafik yang cendering semakin naik seiring bertambah lama penyinaran matahari. Hal tersebut menunjukkan bahwa nilai specific wear rate akan semakin naik dengan semakin lamanya material Ethylene Propylene Diene Monomers (EPDM) terkena sinar matahari. Pada material Ethylene Propylene Diene Monomers (EPDM) yang tidak disinari matahari, volume yang terauskan nilainya paling kecil daripada material yang disinari matahari. Sedangkan pada material yang telah disinari matahari selama 200 jam, volume yang terauskan mempunyai nilai paling besar daripada pada material yang tidak disinari matahari dan material yang telah disinari matahari selama 100 jam. Peningkatan volume 
aus yang terjadi disebabkan karena adanya material debris yang berperan sebagai abrasive yang menambah kekasaran permukaan [4]. Semakin lama bahan karet terkena sinar matahari akan menyebabkan material karet akan semakin keras dan semakin getas sehingga mudah untuk terkikis/terkelupas dan meningkatkan jumlah material debris yang turut menambah keausan dari material tersebut. Material karet akan berubah elastisitasnya sehingga akan menurunkan nilai dari yield strength maupun tensile strength. Penurunan tersebut akan berdampak pada laju keausan yang akan semakin naik.

Pada Gambar 6(a) terlihat bahwa ada permukaan yang terkikis, dapat dilihat dari guratan-guratan lurus yang ditunjukkan dengan anak panah berwarna merah yang mengindikasikan adanya keausan yang bersifat abrasif meskipun hanya sedikit. Pada gambar 6(b) dan gambar 6(c) mekanisme keausan abrasif nampak lebih jelas dengan adanya guratan garis lurus yang lebih banyak yang menunjukkan bahwa keausan yang terjadi lebih besar. Guratan garis lurus yang timbul pada permukaan material diakibatkan oleh adanya wear debris yang berfungsi sebagai bahan abrasive [2]. Dari ketiga hasil foto mikro tersebut dapat diketahui bahwa keausan yang terjadi pada material ethylene propylene diene monomers (EPDM) didominasi oleh keausan yang bersifat abrasif. Tanda panah kuning menunjukkan bahwa gesekan pada pengujian mengakibatkan terjadinya pitting antara material Ethylene Propylene Diene Monomers (EPDM) dengan kaca sehingga material Ethylene Propylene Diene Monomers (EPDM) terkelupas dan menempel pada spesimen uji.

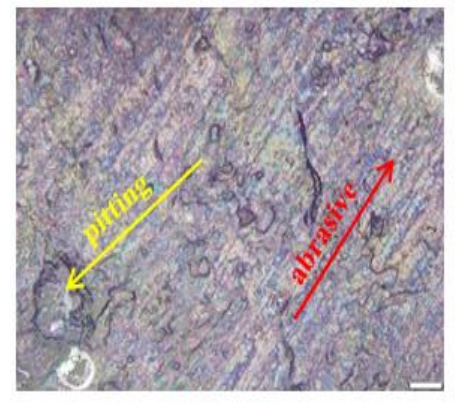

(a)

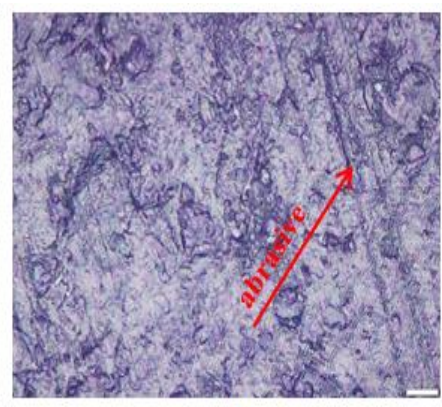

(b)

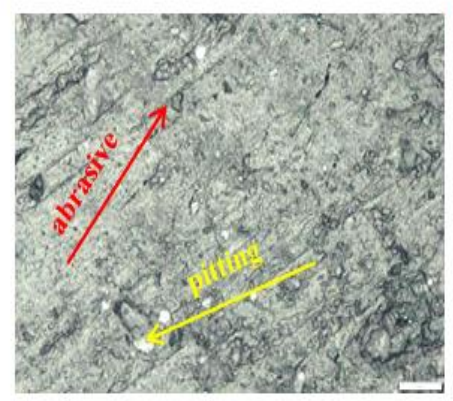

(c)

Gambar 6. Foto Mikro Ethylene Propylene Diene Monomers (EPDM) Perbesaran $100 \mathrm{X}$ : (a) Tanpa penyinaran matahari, (b) 100 jam penyinaran matahari, (c) 200 jam penyinaran matahari.

\section{Nitrile Rubber (NBR)}

Hasil dari pengujian laju keausan pada material Nitrile Rubber (NBR) dapat dilihat pada Tabel 4, 5 dan 6.
Tabel 4

Data perhitungan specific wear rate pada material Nitrile Rubber (NBR) tanpa penyinaran matahari

\begin{tabular}{ccccccc}
\hline \hline $\begin{array}{c}\text { Spesi } \\
\text { men }\end{array}$ & $\begin{array}{c}\Delta \mathrm{m} \\
(\mathrm{gr})\end{array}$ & $\begin{array}{c}\rho \\
\left(\mathrm{gr} / \mathrm{cm}^{3}\right)\end{array}$ & $\begin{array}{c}\Delta \mathrm{V} \\
\left(\mathrm{mm}^{3}\right)\end{array}$ & $\mathrm{s}(\mathrm{m})$ & $\mathrm{F}(\mathrm{N})$ & $\begin{array}{c}\mathrm{K} \\
\left(\mathrm{mm}^{3} / \mathrm{Nm}\right)\end{array}$ \\
\hline 1 & 0,0041 & 1,15 & $\begin{array}{c}1,826086 \\
95\end{array}$ & 1000 & 14,715 & $\begin{array}{c}0,00012409 \\
7\end{array}$ \\
2 & 0,0046 & 1,15 & $\begin{array}{c}2,173913 \\
04\end{array}$ & 1000 & 14,715 & $\begin{array}{c}0,00014773 \\
4\end{array}$ \\
3 & 0,0037 & 1,15 & 2 & 1000 & 14,715 & $\begin{array}{c}0,00013591 \\
6\end{array}$ \\
\hline \hline
\end{tabular}

Tabel 5 .

Data perhitungan specific wear rate pada material Nitrile Rubber (NBR) dengan penyinaran 100 jam

\begin{tabular}{ccccccc}
\hline \hline $\begin{array}{c}\text { Spesi } \\
\text { men }\end{array}$ & $\begin{array}{c}\Delta \mathrm{m} \\
(\mathrm{gr})\end{array}$ & $\begin{array}{c}\rho \\
\left(\mathrm{gr} / \mathrm{cm}^{3}\right)\end{array}$ & $\begin{array}{c}\Delta \mathrm{V} \\
\left(\mathrm{mm}^{3}\right)\end{array}$ & $\mathrm{s}(\mathrm{m})$ & $\mathrm{F}(\mathrm{N})$ & $\begin{array}{c}\mathrm{K} \\
\left(\mathrm{mm}^{3} / \mathrm{Nm}\right)\end{array}$ \\
\hline 1 & 0,0042 & 1,15 & $\begin{array}{c}2,173913 \\
04\end{array}$ & 1000 & 14,715 & $\begin{array}{c}0,00014773 \\
4\end{array}$ \\
2 & 0,0049 & 1,15 & $\begin{array}{c}2,347826 \\
08\end{array}$ & 1000 & 14,715 & $\begin{array}{c}0,00015955 \\
3\end{array}$ \\
3 & 0,0047 & 1,15 & $\begin{array}{c}2,260869 \\
56\end{array}$ & 1000 & 14,715 & $\begin{array}{c}0,00015364 \\
4\end{array}$ \\
\hline \hline
\end{tabular}

Tabel 6

Data perhitungan specific wear rate pada material Nitrile Rubber (NBR) dengan penyinaran 200 jam

\begin{tabular}{ccccccc}
\hline \hline $\begin{array}{c}\text { Spesi } \\
\text { men }\end{array}$ & $\begin{array}{c}\Delta \mathrm{m} \\
(\mathrm{gr})\end{array}$ & $\begin{array}{c}\rho \\
\left(\mathrm{gr} / \mathrm{cm}^{3}\right)\end{array}$ & $\begin{array}{c}\Delta \mathrm{V} \\
\left(\mathrm{mm}^{3}\right)\end{array}$ & $\mathrm{s}(\mathrm{m})$ & $\mathrm{F}(\mathrm{N})$ & $\begin{array}{c}\mathrm{K} \\
\left(\mathrm{mm}^{3} / \mathrm{Nm}\right)\end{array}$ \\
\hline 1 & 0,0046 & 1,15 & $\begin{array}{c}2,434782 \\
60\end{array}$ & 1000 & 14,715 & $\begin{array}{c}0,00016546 \\
3\end{array}$ \\
2 & 0,005 & 1,15 & $\begin{array}{c}2,695652 \\
17\end{array}$ & 1000 & 14,715 & $\begin{array}{c}0,00018319 \\
1\end{array}$ \\
3 & 0,0057 & 1,15 & $\begin{array}{c}2,608695 \\
65\end{array}$ & 1000 & 14,715 & $\begin{array}{c}0,00017728 \\
1\end{array}$ \\
\hline \hline
\end{tabular}

D.Analisa Laju Keausan Pada Material Nitrile Rubber (NBR)

Dari data yang ada, dapat dianalisa berapa nilai specific wear rate yang menunjukkan besarnya volume aus atau bagian yang terkikis setiap satu satuan gaya dan jarak. Besarnya specific wear rate untuk material Ethylene Propylene Diene Monomers (EPDM) dapat dilihat pada Gambar 7.

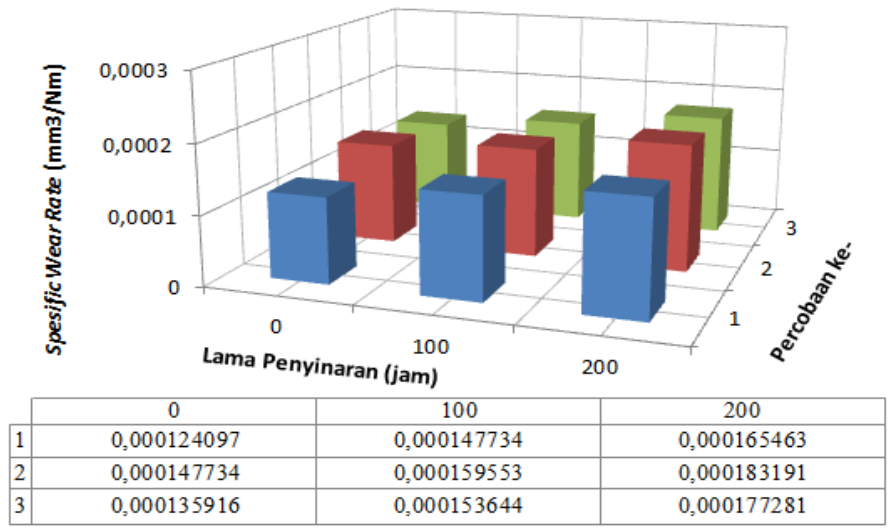

Gambar 7. Grafik Specific Wear Rate terhadap Lama Penyinaran Matahari pada material Nitrile Rubber (NBR).

Dari Gambar 7, dapat dilihat bahwa pada material nitrile rubber $(N B R)$ dilakukan 3 kali percobaan untuk setiap variasi penyinaran dengan menghasilkan nilai specific wear rate yang tidak terlalu berbeda jauh. 


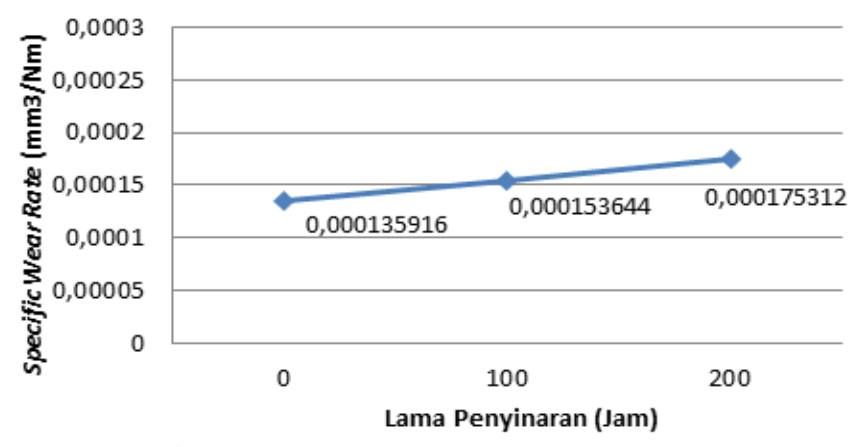

Gambar 8. Grafik Specific Wear Rate Rata-rata terhadap Lama Penyinaran Matahari pada Material Nitrile Rubber (NBR).

Pada Gambar 8, terlihat tren grafik yang cendering semakin naik seiring bertambah lama penyinaran matahari. Hal tersebut menunjukkan bahwa nilai specific wear rate akan semakin naik dengan semakin lamanya material Nitrile Rubber (NBR) terkena sinar matahari. Volume material Nitrile Rubber $(N B R)$ yang terauskan nilainya tidak terlalu signifikan perubahannya. Pada material Nitrile Rubber (NBR) yang tidak disinari matahari, volume yang terauskan nilainya paling kecil daripada material yang disinari matahari. Sedangkan pada material yang telah disinari matahari selama 200 jam, volume yang terauskan mempunyai nilai paling besar daripada pada material yang tidak disinari matahari dan material yang telah disinari matahari selama 100 jam. Peningkatan volume aus yang terjadi disebabkan karena adanya material debris yang berperan sebagai abrasive yang menambah kekasaran permukaan [4]. Semakin lama bahan karet terkena sinar matahari akan menyebabkan material karet akan semakin keras dan semakin getas sehingga mudah untuk terkikis/terkelupas dan meningkatkan jumlah material debris yang turut menambah keausan dari material tersebut. Material karet akan berubah elastisitasnya sehingga akan menurunkan nilai dari yield strength maupun tensile strength. Penurunan tersebut akan berdampak pada laju keausan yang akan semakin naik.

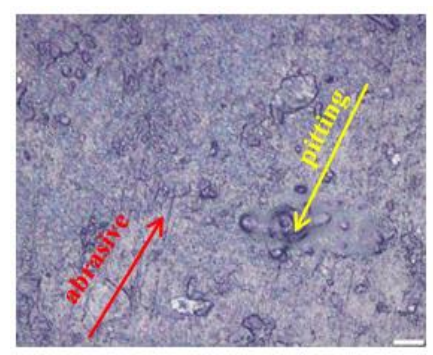

(a)

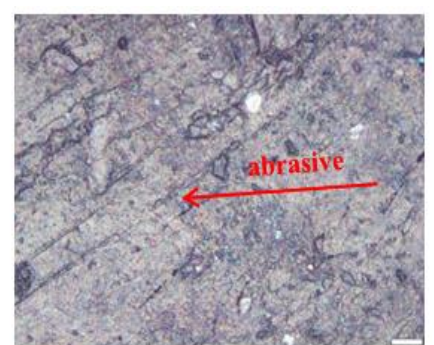

(b)



(c)

Gambar 9. Foto Mikro Nitrile Rubber $(N B R)$ : (a). Tanpa penyinaran matahari, (b) 100 jam penyinaran matahari, (c) 200 jam penyinaran matahari.
Pada Gambar 9(a) terlihat bahwa ada permukaan yang terkikis, dapat dilihat dari guratan-guratan lurus yang ditunjukkan dengan anak panah berwarna merah yang mengindikasikan adanya keausan yang bersifat abrasif meskipun hanya sedikit. Tanda panah kuning menunjukkan bahwa gesekan pada pengujian mengakibatkan terjadinya pitting antara material Nitrile Rubber (NBR) dengan kaca sehingga material Nitrile Rubber (NBR) terkelupas dan menempel pada spesimen uji. Pada Gambar 9(b) dan gambar 9(c) mekanisme keausan abrasif nampak lebih jelas dengan adanya guratan garis lurus yang lebih banyak yang menunjukkan bahwa keausan yang terjadi lebih besar. Guratan garis lurus yang timbul pada permukaan material diakibatkan oleh adanya wear debris yang berfungsi sebagai bahan abrasive [2]. Dari ketiga hasil foto mikro tersebut dapat diketahui bahwa keausan yang terjadi pada material Nitrile Rubber (NBR) didominasi oleh keausan yang bersifat abrasif.

\section{E. Perbandingan Keausan Nitrile Rubber (NBR) dan Ethylene Propylene Diene Monomers (EPDM)}

Pada pengujian keausan yang dilakukan pada material Ethylene Propylene Diene Monomers (EPDM) dan material Nitrile Rubber (NBR) dapat diketahui bahwa pada kedua material akan mengalami keausan yang semakin besar seiring dengan semakin lamanya penyinaran matahari. Perbandingan specific wear rate yang didapatkan dari pengujian keausan material Ethylene Propylene Diene Monomers (EPDM) dan Nitrile Rubber (NBR) dapat dilihat seperti Gambar 10.

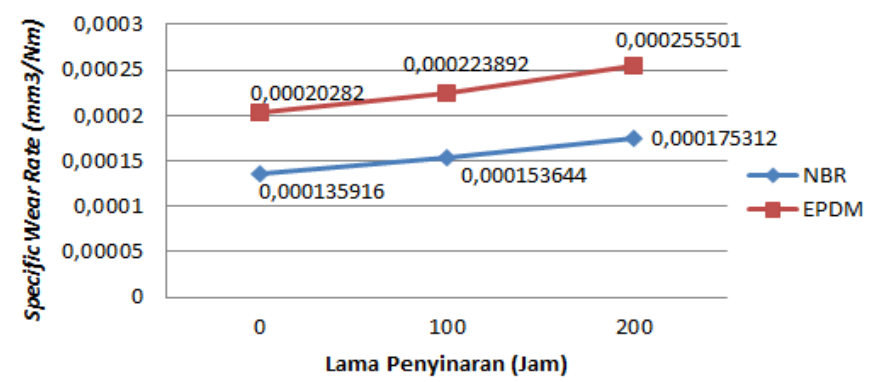

Gambar 10. Grafik Perbandingan Specific Wear Rate Material Ethylene Propylene Diene Monomers dan Nitrile Rubber.

Tabel 7.

Data perhitungan specific wear rate pada material Nitrile Rubber (NBR) dengan penyinaran $200 \mathrm{jam}$

\begin{tabular}{ccccc}
\hline \hline Material & $\begin{array}{c}\text { Penyinaran } \\
\text { (jam })\end{array}$ & $\begin{array}{c}\text { Specific Wear } \\
\text { Rate } \mathrm{K} \\
\left(\mathrm{mm}^{3} / \mathrm{Nm}\right)\end{array}$ & $\begin{array}{c}\Delta \mathrm{K} \\
\left(\mathrm{mm}^{3} / \mathrm{Nm}\right)\end{array}$ & Persentase\% \\
\hline \multirow{4}{*}{ EPDM } & 0 & 0,00020282 & 0 & 0 \\
& 100 & 0,000223892 & $1,77281 \mathrm{E}-05$ & $\begin{array}{c}10,3896103 \\
9\end{array}$ \\
& 200 & 0,000255501 & $2,16677 \mathrm{E}-05$ & $\begin{array}{c}14,1176470 \\
6\end{array}$ \\
& 0 & 0,000135916 & 0 & 0 \\
NBR & 100 & 0,000153644 & $2,10722 \mathrm{E}-05$ & 13,0434782 \\
& 200 & 0,000175312 & $3,16083 \mathrm{E}-05$ & 14,1025641 \\
\hline \hline
\end{tabular}

Pada Gambar 10 dapat dilihat bahwa pada kedua material memiliki tren grafik yang sama dimana semakin lama penyinaran matahari, nilai specific wear rate akan semakin naik juga akan tetapi tren grafik material Ethylene Propylene Diene Monomers (EPDM) berada di atas tren grafik material 
Nitrile Rubber (NBR). Besarnya kenaikan nilai specific wear rate pada kedua material tersebut dapat dilihat pada Tabel 7 .

Dari Gambar 10 dan Tabel 7, dapat diketahui bahwa material Ethylene Propylene Diene Monomers (EPDM) memiliki ketahanan terhadap pancaran sinar matahari yang lebih baik daripada material Nitrile Rubber $(N B R)$, tetapi mempunyai ketahanan aus yang lebih rendah daripada material Nitrile Rubber (NBR).

\section{F. Perhitungan Umur Hidup (Life Time) Material}

Setelah dilakukan perhitungan nilai specific wear rate, selanjutnya dilakukan perhitungan umur hidup (life time) material Ethylene Propylene Diene Monomers (EPDM) dan material Nitrile Rubber (NBR). Hasil dari perhitungan yang dilakukan dapat dilihat pada Tabel 8 dan 9.

Tabel 8.

Perhitungan Umur Hidup Material Ethylene Propylene Diene Monomers (EPDM)

\begin{tabular}{|c|c|c|c|c|c|c|c|}
\hline $\begin{array}{c}\text { Penyin } \\
\text { aran } \\
\text { (jam) }\end{array}$ & $\begin{array}{c}\Delta \mathrm{V} \\
\left(\mathrm{mm}^{3}\right)\end{array}$ & $\begin{array}{c}\mathrm{K} \\
\left(\mathrm{mm}^{3} / \mathrm{N}\right. \\
\mathrm{m})\end{array}$ & $\mathrm{W}(\mathrm{N})$ & $\begin{array}{c}\mathrm{L} \\
(\mathrm{m})\end{array}$ & $\mathrm{v}(\mathrm{m} / \mathrm{s})$ & $\mathrm{t}(\mathrm{s})$ & $\begin{array}{c}\mathrm{t} \\
(\mathrm{tahu} \\
\mathrm{n})\end{array}$ \\
\hline 0 & 9429,658 & $\begin{array}{c}0,000202 \\
82\end{array}$ & 14,71 & $\begin{array}{c}31606 \\
21,8\end{array}$ & 0,1312 & $\begin{array}{c}24090 \\
105\end{array}$ & 3,7 \\
\hline 100 & 9429,658 & $\begin{array}{c}0,000223 \\
89\end{array}$ & 14,71 & $\begin{array}{c}28631 \\
51,5\end{array}$ & 0,1312 & $\begin{array}{c}21822 \\
801\end{array}$ & 3,3 \\
\hline 200 & 9429,658 & $\begin{array}{c}0,000255 \\
50\end{array}$ & 14,71 & $\begin{array}{c}25089 \\
47,2\end{array}$ & 0,1312 & $\begin{array}{c}19123 \\
073\end{array}$ & 2,9 \\
\hline
\end{tabular}

Tabel 9.

Perhitungan Umur Hidup Material Nitrile Rubber (NBR)

\begin{tabular}{|c|c|c|c|c|c|c|c|}
\hline $\begin{array}{c}\text { Penyin } \\
\text { aran } \\
\text { (jam) }\end{array}$ & $\underset{\left(\mathrm{mm}^{3}\right)}{\Delta \mathrm{V}}$ & $\begin{array}{c}\mathrm{K} \\
\left(\mathrm{mm}^{3} / \mathrm{N}\right. \\
\mathrm{m})\end{array}$ & $\mathrm{W}(\mathrm{N})$ & $\begin{array}{c}\mathrm{L} \\
(\mathrm{m})\end{array}$ & $\mathrm{v}(\mathrm{m} / \mathrm{s})$ & $\mathrm{t}(\mathrm{s})$ & $\begin{array}{c}\mathrm{t} \\
(\operatorname{tahu} \\
\mathrm{n})\end{array}$ \\
\hline 0 & 9429,658 & $\begin{array}{c}0,0001 \\
3591\end{array}$ & 14,71 & $\begin{array}{c}47164 \\
31,8\end{array}$ & 0,1312 & $\begin{array}{c}35948 \\
413\end{array}$ & 5,5 \\
\hline 100 & 9429,658 & $\begin{array}{c}0,0001 \\
5364\end{array}$ & 14,71 & $\begin{array}{c}41722 \\
28,1\end{array}$ & 0,1312 & $\begin{array}{c}31800 \\
519\end{array}$ & 4,8 \\
\hline 200 & 9429,658 & $\begin{array}{c}0,0001 \\
7531 \\
\end{array}$ & 14,71 & $\begin{array}{c}36565 \\
59,5 \\
\end{array}$ & 0,1312 & $\begin{array}{c}27870 \\
118 \\
\end{array}$ & 4,2 \\
\hline
\end{tabular}

Dari Tabel 8 dan 9 dapat kita ketahui bahwa umur hidup (life time) material Ethylene Propylene Diene Monomers $(E P D M)$ terbaik berada pada sekitaran 3,7 tahunan. Nilai tersebut lebih kecil daripada umur hidup (life time) material Nitrile Rubber (NBR) terbaik yang nilainya sekitar 5,5 tahunan. Nilai umur hidup (life time) terbaik didapatkan dengan melakukan perhitungan pada material yang tidak disinari matahari. Lama umur hidup (life time) kedua material didapatkan dengan mengasumsikan bahwa penggunaan wiper rata-rata 5 jam setiap hari. Jika dibandingkan, umur hidup (life time) material Nitrile Rubber (NBR) lebih lama sekitar 1,5 kali daripada umur hidup (life time) Ethylene Propylene Diene Monomers (EPDM). Dari data di atas, dapat diketahui bahwa umur hidup (life time) material Ethylene Propylene Diene Monomers (EPDM) dan material Nitrile Rubber (NBR) akan semakin menurun seiring dengan semakin lamanya material terkena sinar matahari. Umur hidup yang didapatkan dari hasil pengujian ini nilainya lebih kecil daripada umur hidup dari material pada keadaan yang sesungguhnya. Hal ini dikarenakan pada pengujian ini dilakukan pada keadaan kering, sedangkan pada kondisi yang sebenarnya wiper bekerja pada kondisi hujan atau dalam kondisi basah sehingga keausan yang terjadi pada pengujian ini akan lebih besar.

\section{KESIMPULAN}

Dari hasil pengujian dan analisa yang dilakukan dapat disimpulkan :

1. Semakin lama material Ethylene Propylene Diene Monomers (EPDM) dan material Nitrile Rubber (NBR) terkena sinar matahari akan menyebabkan material semakin keras dan getas sehingga akan menurunkan elastisitasnya yang mengakibatkan specific wear rate semakin naik dan membuat material lebih mudah terauskan.

2. Umur hidup (life time) terbaik dari material Ethylene Propylene Diene Monomers (EPDM) adalah sekitar 3,7 tahun dan umur hidup (life time) terbaik untuk material Nitrile Rubber (NBR) adalah sekitar 5,5 tahun, dimana umur hidup (life time) yang diperoleh dari penelitian ini lebih singkat daripada pada kondisi sesungguhnya karena pada penelitian ini pengujian dilakukan pada kondisi terburuk yaitu pada kondisi kering sedangkan pada kondisi sesungguhnya wiper bekerja pada kondisi basah.

3. Material Nitrile Rubber (NBR) memiliki ketahanan terhadap aus yang lebih baik serta mempunyai umur hidup 1,5 kali lebih lama daripada material Ethylene Propylene Diene Monomers (EPDM) sehingga material Nitrile Rubber (NBR) dapat dijadikan sebagai alternatif pengganti material Ethylene Propylene Diene Monomers (EPDM).

\section{DAFTAR PUSTAKA}

[1] A. Koenen and A. Sanon., "Tribological and Vibroacoustic Behavior of a Contact Between Rubber and Glass (Application to Wiper Blade)," J. Tribol. Int., vol. 40, pp. 1484-1491, 2007.

[2] T. Prayogi, "Rancang Bangun Tribometer Tipe Pin on Disk dan Studi Eksperimental Karakteristik Tribology Polimer-polimer," Surabaya, 2010.

[3] E. Ningsih and Y. Kaelani, "Studi Eksperimen dan Analisa Keausan Journal Bearing Dry Contact pada Rotary Valve Mesin Pembuat Pasta," J. Tek. ITS, vol. 5, no. 1, 2016.

[4] R. Kurnia and Y. Kaelani, "Identification method for stick slip contact within multi directional contact friction," in AIP Conference Proceedings, 1983. 